\title{
Roadmap for Lean implementation in Indian automotive component manufacturing industry: comparative study of UNIDO Model and ISM Model
}

\author{
J. R. Jadhav $\cdot$ S. S. Mantha $\cdot$ S. B. Rane
}

Received: 10 February 2014 / Accepted: 20 June 2014/Published online: 30 July 2014

(C) The Author(s) 2014. This article is published with open access at Springerlink.com

\begin{abstract}
The demands for automobiles increased drastically in last two and half decades in India. Many global automobile manufacturers and Tier-1 suppliers have already set up research, development and manufacturing facilities in India. The Indian automotive component industry started implementing Lean practices to fulfill the demand of these customers. United Nations Industrial Development Organization (UNIDO) has taken proactive approach in association with Automotive Component Manufacturers Association of India (ACMA) and the Government of India to assist Indian SMEs in various clusters since 1999 to make them globally competitive. The primary objectives of this research are to study the UNIDO-ACMA Model as well as ISM Model of Lean implementation and validate the ISM Model by comparing with UNIDO-ACMA Model. It also aims at presenting a roadmap for Lean implementation in Indian automotive component industry. This paper is based on secondary data which include the research articles, web articles, doctoral thesis, survey reports and books on automotive industry in the field of Lean, JIT and ISM. ISM Model for Lean practice bundles was developed by authors in consultation with Lean practitioners. The UNIDO-ACMA Model has
\end{abstract}

\section{J. R. Jadhav $(\bowtie) \cdot$ S. B. Rane}

Department of Mechanical Engineering, Sardar Patel College of

Engineering, Bhavan's Campus, Munshi Nagar, Andheri (West),

Mumbai 400 058, India

e-mail: jrjadhav70@gmail.com

S. B. Rane

e-mail: ranesantoshb@yahoo.co.in

\section{S. S. Mantha}

All India Council for Technical Education (AICTE), 7th Floor, Chanderlok Building, Janpath, New Delhi 110 001, India

e-mail: ssmantha@vjti.org.in six stages whereas ISM Model has eight phases for Lean implementation. The ISM-based Lean implementation model is validated through high degree of similarity with UNIDO-ACMA Model. The major contribution of this paper is the proposed ISM Model for sustainable Lean implementation. The ISM-based Lean implementation framework presents greater insight of implementation process at more microlevel as compared to UNIDOACMA Model.

Keywords Lean · Just-in-time (JIT) · Automotive component manufacturing - Lean practices - Strategies . Interpretive structural modeling (ISM) · United Nations Industrial Development Organization (UNIDO) . Automotive Component Manufacturers Association of India (ACMA)

\section{Introduction}

India has become manufacturing hub for many global automobile 'Original Equipment Manufacturers' (OEM) and Tier-1 suppliers. They aggressively demand cost-effective quality products with in time on line delivery from their vendors. Small medium enterprise (SME) is facing the pressure from its competitors; mainly large companies as they could provide products of greater value with lower cost as compared to SMEs (Jie et al. 2014). Challenges in today's global competition have forced or required manufacturing firms to look for appropriate manufacturing management strategies in order to enhance their efficiency and competitiveness (Lila 2012). To meet the challenge of offering high standards of quality, cost and delivery (QCD) to these multinational OEMs, Indian manufacturing SMEs must implement effective approaches, such as Lean manufacturing, to 
continually and systematically improve their operations (Saboo et al. 2014). To remain competitive in fierce global competition, the Indian automotive component industry needs to have paradigm shift in their thinking to improve its production capabilities, productivity, quality and scalability. Implementation of Lean systems has become inevitable to survive in the market.

According to Panizzolo et al. (2012), the powerful Lean manufacturing approach that has proved successful as an operations' model in developed economies, as well as in some large Indian companies, is now increasingly being recognized by the small- and medium-sized enterprises (SMEs). In the last 10 years, even the manufacturers located in the developing countries such as China and India are also working to transform their manufacturing base from traditional low-cost, labourintensive 'Fordist' production to higher value, more flexible and more productive 'Lean' manufacturing systems (Panizzolo et al. 2012). Currently, in India about 150 companies in the automobile industry use Lean manufacturing, but it is yet to permeate other areas (Mehta et al. 2012).

There are certain obstacles in the implementation of Lean manufacturing practices. But they can be overcome by successful planning (Mehta et al. 2012). To overcome the challenges in dynamic global market and for propagation of Lean practices, the partnership program was designed and developed by United Nations Industrial Development Organization (UNIDO) in collaboration with Automotive Component Manufacturers Association of India (ACMA) and the Government of India to support small and medium enterprises (SMEs) in the automotive component sector. The formation of regional clusters consists of $8-10$ component manufacturers; each is the focal constituent of this program. Many Lean practices were implemented in more than 130 component manufacturers in three project phases (1999-2010) under the guidance of independent and external UNIDO-trained counselor. Many engineers and upgrading experts of UNIDO, staff of participating company, and members of support organizations have been trained in Lean practices to carry out shop-floor interventions. The progress of shopfloor interventions was monitored and tracked through monthly peer review meetings directed by the counselor at the company level on the basis of key performance indicators (KPI) and mutual learning with other cluster companies through the benchmarking. Many automotive component manufacturing companies were in position to enhance their capacity/capability and develop their skills to participate in a comprehensive continuous improvement program. Benchmarking the progress with peer companies in the same geographical zone empowered participating companies to develop and execute their own vision and mission, including better capacity utilization, better employee participation and healthier labour-management relationships.

The authors have developed a framework for sustainable Lean implementation based on interpretive structural modeling (ISM) methodology. Original theoretical development of ISM is credited to J.W. Warfield. Sage and Smith (1977), Sage (1977) and Farris and Sage (1975) have contributed to the development and application of the ISM methodology for a variety of purposes-especially those concerned with decision analysis and worth assessment in large-scale systems. Interpretive structural modeling is a tool which permits identification of structure within a system. The system may be large or small in terms of numbers of elements; and it is the larger, complex systems which benefit the most from interpretive structural modeling (Farris and Sage 1975). The ISM process transforms unclear, poorly articulated mental models of systems into visible, well-defined models useful for many purposes (Mishra et al. 2012; Ahuja et al. 2009). Interpretive structural modeling (ISM) can be used for identifying and summarizing relationships among specific variables, which define a problem or an issue (Sage 1977; Warfield 1974). It provides us a means by which order can be imposed on the complexity of such variables (Jharkharia and Shankar 2005; Mandal and Deshmukh 1994).

ISM has been used by researchers for understanding direct and indirect relationships among various variables in different industries. Satapathy and Mishra (2013) applied ISM to find interrelationship between design requirements for service quality of electricity utility sector. Kumar et al. (2013) used ISM to model variables for effective customer involvement in green concept implementation in supply chain management. Diabat et al. (2012) analyses the various risks involved in a food supply chain with the help of ISM. Faisal et al. (2007) used ISM to analyses the enablers for supply chain agility. ISM is a well-known technique, which can be applied in various fields. ISM has been applied by a number of researchers to develop a better understanding of the systems under consideration (Mudgal et al. 2010). ISM-based criteria model for the selection of reverse logistics provider was developed by Kannan et al. (2009). Ravi and Shankar (2005) analyzed the barriers of the reverse logistics in automobile industries using the ISM methodology, which shows the interrelationships of the barriers and their levels. Khurana et al. (2010) used ISM for modeling of information sharing enablers for building trust in Indian manufacturing industry. Interpretive structural modeling of risk sources in a virtual organization was carried out by Alawamleh and Popplewell (2011).

The prime purposes of this paper are to study and compare the UNIDO-ACMA Model of Lean implementation and validate the ISM Model through comparison with UNIDO- 
ACMA Model. It also aims at offering a framework for Lean implementation in automotive component industry. The research is based on secondary data, which include compilation of research articles, web articles, survey reports, thesis and books, etc. on automotive industry.

The main aspect of the paper is the framework for sustainable Lean implementation through interpretive structural modeling. The key contribution of this paper is the structural model for Lean implementation with input variables, the process, the anticipated outcomes and its impact on business.

The salient features of the research are:

1. It provides the understanding of Lean implementation process model adopted by UNIDO-ACMA.

2. It represents the collective wisdom of Lean practitioners in the form of interpretive structural Model.

3. It provides the crystal clear information of necessary input, the process, the expected as well as desired outcomes and its impact on the business.

4. It offers phase-wise road map for sustainable Lean implementation based on ISM.

5. It provides greater level of understanding of execution process at further microlevel as compare to UNIDOACMA Model.

This paper is further organized as follows. Research objective and research methodology are described in second section. Section three contains overview of India's automotive and auto component manufacturing industry. The UNIDO-ACMA Model approach (the partnership roadmap) is introduced briefly in section four. Section five presents the description of ISM-based model for Lean practice bundles. The comparison of UNIDO-ACMA Model and ISM Model for Lean implementation is discussed in section six. Section seven presents the general conclusions with research findings, implications. Section eight and nine contain the limitation of research study and suggestions for future research, respectively.

\section{Research objectives and methodology}

Research objectives

The main objectives of this paper are:

1. To study the UNIDO-ACMA Model and ISM Model of Lean implementation.

2. To compare UNIDO-ACMA Model and ISM Model of Lean implementation.

3. To validate the ISM Model by comparing with UNIDO-ACMA Model.
Research methodology

The research brings out the similarities and differences of both models. This work can be considered as a roadmap to develop a deployment strategy for successful Lean implementation. First the relevant literature is reviewed. The literature survey was augmented using online computerized database like Taylor and Francis, Science Direct, Google Scholar, Bing, etc. using primary keywords such as just-intime (JIT), Lean, Lean supply, JIT manufacturing, ISM, automotive, automotive components, etc. and secondary key words like practices, benchmarking, modeling, framework, etc.

This research is based on secondary data, which comprise of the research articles, web articles, doctoral thesis, survey reports and books on automotive industry in the domain of Lean, JIT and ISM. ISM Model for Lean practice bundles was developed by authors in consultation with four Lean practitioners based in Maharashtra state of India. The development of ISM Model is not presented as it is out of scope of this paper.

The flowchart of research methodology used in this study is shown in Fig. 1.

Final ISM Model for Lean practice bundles was developed as shown in Fig. 11 based on the input from the team members comprising of Lean/JIT practitioners and experts using ISM technique. ISM Model requires examination of direct and indirect relationships between the Lean practice bundles rather than considering these Lean practice bundles in separation. This analysis will help the managers to devise the strategy for rolling out the Lean/JIT in their organization. The ISM Model was compared with UNIDOACMA Model. Both models were analyzed. The discussion highlights the vast similarities and very little difference between two models.

\section{Overview of India's automotive industry}

The automotive industry includes the OEM and auto component manufacturers. The automotive industry plays significant role in the development and economic growth of any country. Automobile industry in India grows with leap and bounds since 1991 due to change in industrial polices specifically liberalization and de-licensing of many segments by Government of India. Many foreign automobile companies also started joint ventures with prevailing Indian companies.

The Indian automotive industry is witnessing a phase of rapid transformation and growth, mainly driven by stable economic growth and infrastructure development (Wipro 2013). Today India has become the manufacturing hub for global automotive giant companies like Toyota, Honda, 
Fig. 1 Flowchart for research methodology

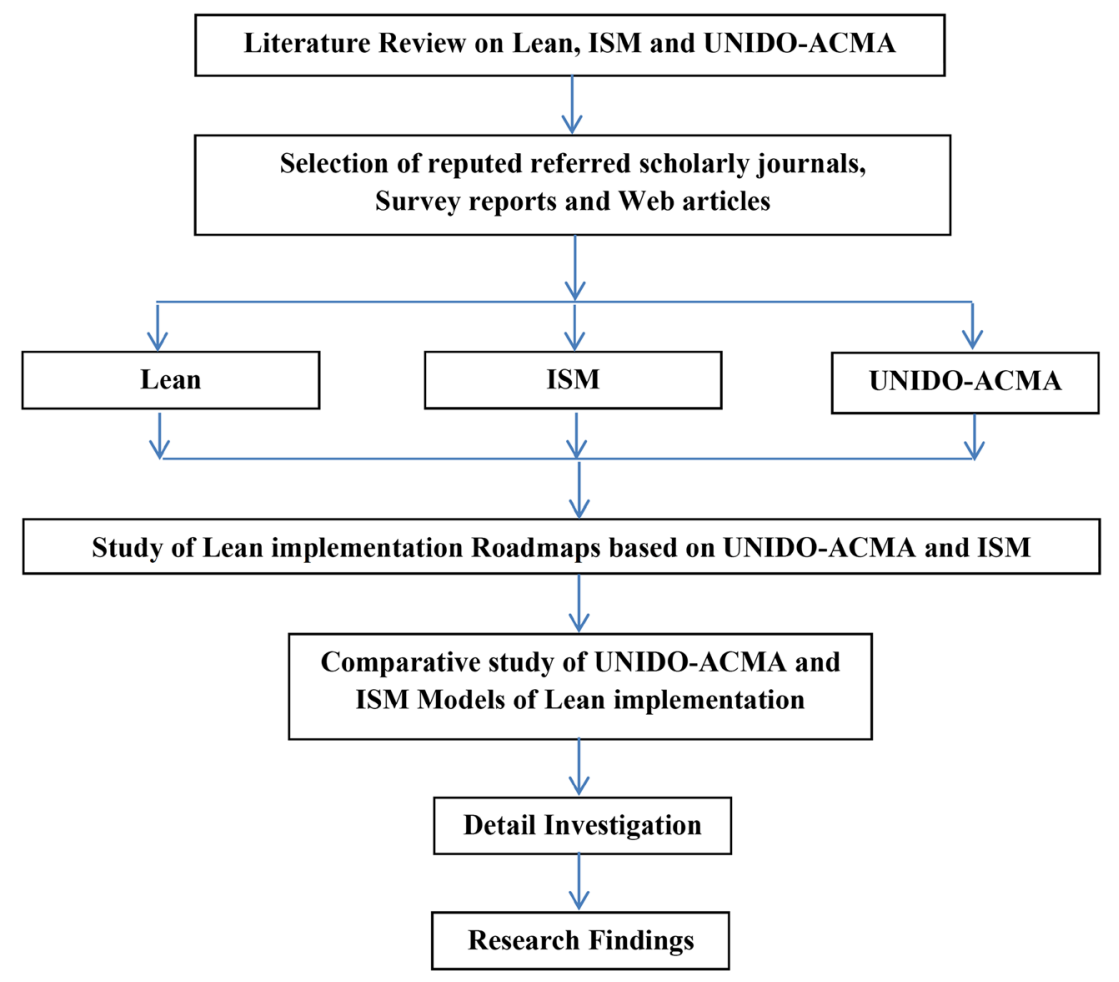

Suzuki, Nissan, Hyundai, General Motors, Ford, Fiat, Renault, Mitsubishi, BMW, Daimler etc. The automobile manufacturers of two wheelers, three wheelers, passenger cars, passenger vehicles, multi-purpose vehicles (MPV), commercial vehicles and auto components have created vast opportunities of employment and growth.

The automobile segment product categories are shown in Fig. 2. Automobile segments are mainly classified into four segment namely passenger vehicles, commercial vehicles, three wheelers and two wheelers. Passenger vehicles include cars, utility vehicles and multi-purpose vehicles. Commercial vehicles include light, medium and heavy commercial vehicles. Three wheelers comprise of passenger carriers and goods carriers. Two wheelers include motorcycles, scooters, mopeds and electric vehicles.

Figure 3 shows the production and sales of $4 / 6$ wheelers and 2/3 wheelers industry for year 2011-2012 and 2012-2013. In 4/6 wheelers industry, the contribution of passenger vehicles (car, MPVs and UVs) is much higher than other categories of $4 / 6$ wheelers. In $2 / 3$ wheelers industry, the contribution of motorcycles/step-throughs is much higher than other categories of $2 / 3$ wheelers.

CII SR quarterly update (2009) reported that two wheelers (2Ws), being the most popular means of personal transport, alone account for about $77 \%$ of the total automobile production in India, while passenger vehicles (PVs) account for over $15 \%$ of the sales. However, owing to their lower sales realizations, two wheelers account for only around $32 \%$ of the sales in terms of value while PVs account for around $62 \%$ of the same.

Figure 4 shows Indian automobile industry exports from year 2007 to 2013. A continual increase in Indian automobile industry exports is observed. According to India Brand Equity Foundation (IBEF) (2014), the overall automobile exports grew by 2.03 percent during April-August 2013. According to IBEF (2014), India is set to be among top five automobile producers by 2015 . The drivers for this rapid growth are high demand due to expanding middle class population with rising income, young population base, availability of skilled manpower, propagation of modern/advance technology. The statistics related to Indian Automotive Industry mentioned here are published by IBEF. According to the data published by ACMA, the production of passenger vehicles in India was recorded at 3.23 million in 2012-2013 and is estimated to grow at a compound annual growth rate (CAGR) of 13 percent during 2012-2021. The overall automobile exports grew by 2.03 percent during April-August 2013. The Indian automobile industry produced a total 1.69 million vehicles including passenger vehicles, commercial vehicles, three wheelers and two wheelers in August 2013 as against 1.56 million in August 2012, registering a growth of 8.18 percent over the same month last year. The cumulative foreign direct investment (FDI) inflow into the Indian automobile industry during April 2000 to July 2013 was recorded at US\$ 8,932 million, amounting to 4.5 percent of the total FDI inflows (in terms of US\$), as per data published by 
Fig. 2 Automobile segment product categories (sources: SIAM, ImaCS and CII SR quarterly Update 2009). SIAM society of Indian automobile manufacturers, IMaCS ICRA management consulting services limited, CII confederation of Indian industries

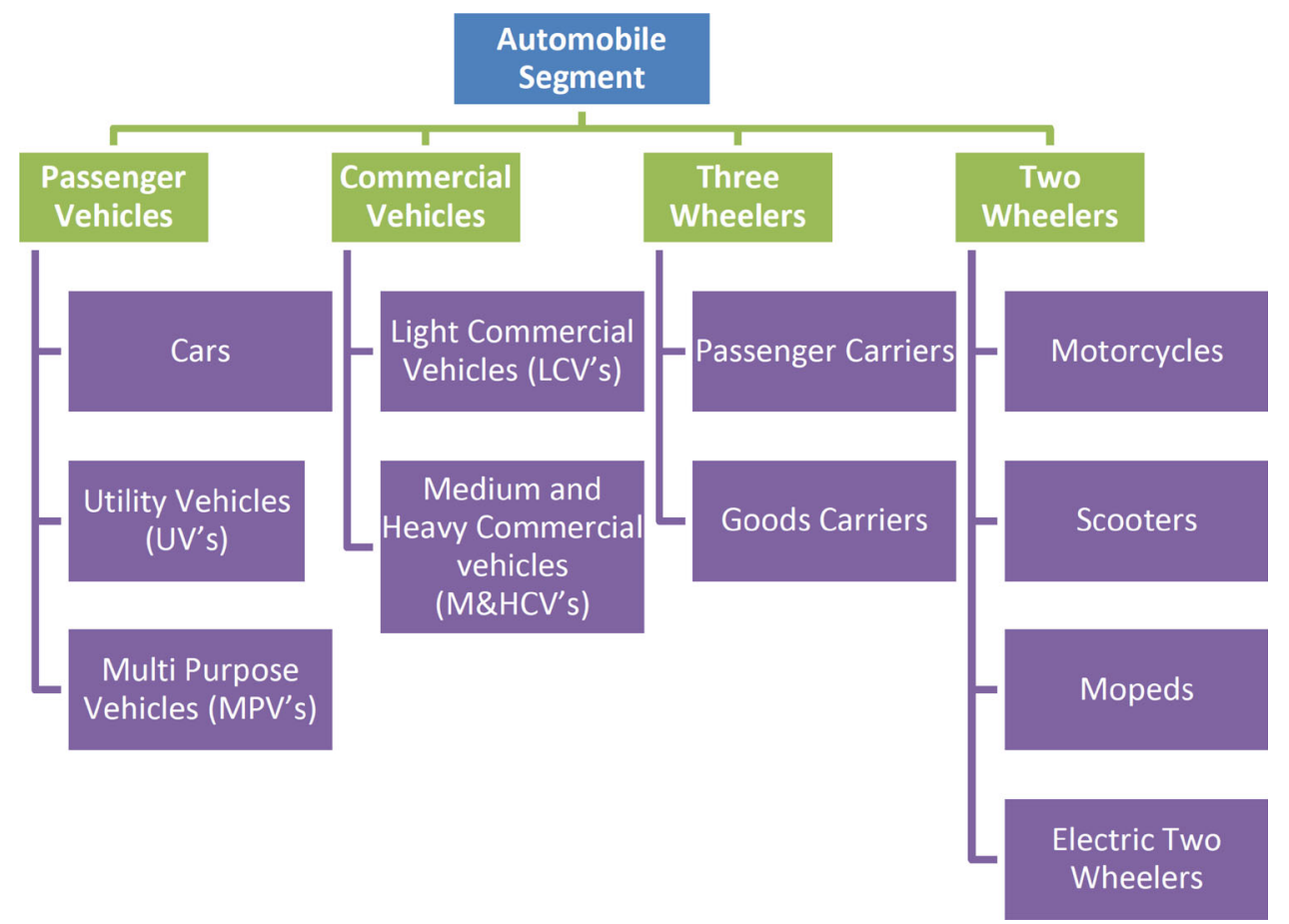

Department of Industrial Policy and Promotion (DIPP), Ministry of Commerce. According to a research report by Espirito Santo Securities, the Indian auto and auto components Industry can be expected to surpass China's growth path by 2021 (Barreto 2013).

Automotive component manufacturers association of India (ACMA)

The All India Automobile \& Ancillary Industries Association (AIA \& AIA) was established in 1959. It was renamed as ACMA of India in 1982. It is the apex body of the Indian automotive component manufacturing industry. It has more than 650 member companies mainly from auto component manufacturers in India in the organized sector. ACMA member companies contribute more than $85 \%$ of the total auto component production. ACMA member companies cater the needs of domestic vehicle manufacturers as-as OEM, to tier-one vendors, to state transport undertakings, railways, defence organizations and even to the spare parts market. A variety of auto components are also being exported to OEMs and after-markets worldwide. ACMA is actively involved in strengthening the automotive supply chain and enhancing competitiveness of the auto component industry in India through its technology division-ACMA Center for Technology (ACT). ACMA endorses Indian automotive component industry for trade promotion, technology up-gradation, quality improvement, collection and transmission of information. Each one of these is a significant reagent for development and growth of industry.

Automotive industry clusters in India

Demand for two wheelers and four wheelers have been rising since 1990 in India. As a result, subcontracting propagates between automobile assemblers (i.e., OEM) and tier-one vendors and between tier-one and tier-two vendors. Small and medium enterprises (SMEs) moved into the rapidly growing market of auto components manufacturing in clusters. Although large enterprise with foreign and technical collaboration with foreign companies has maintained major share of critical components, SMEs which started business in the 1980s and 1990s, have grown. Some of them graduated from SMEs and became large enterprises (Uchikawa and Roy 2013). Today component suppliers offer their own design solutions, do value engineering, and instead of supplying only components, they are beginning to supply automotive systems (Wipro 2013).

The Indian and global OEM's established in the cluster zones are depicted in Fig. 5. At present auto component industry has developed in three major and one minor automotive cluster zones viz. North India, West India, South India and East India. North India zone is established in Haryana-Delhi National Capital Region (NCR) (Delhi, Gurgaon, Manesar, Faridabad, Rewari, Gautam Budh Nagar and Ghaziabad districts). West India Cluster is established in Maharashtra (Mumbai, Pune, Nasik and 


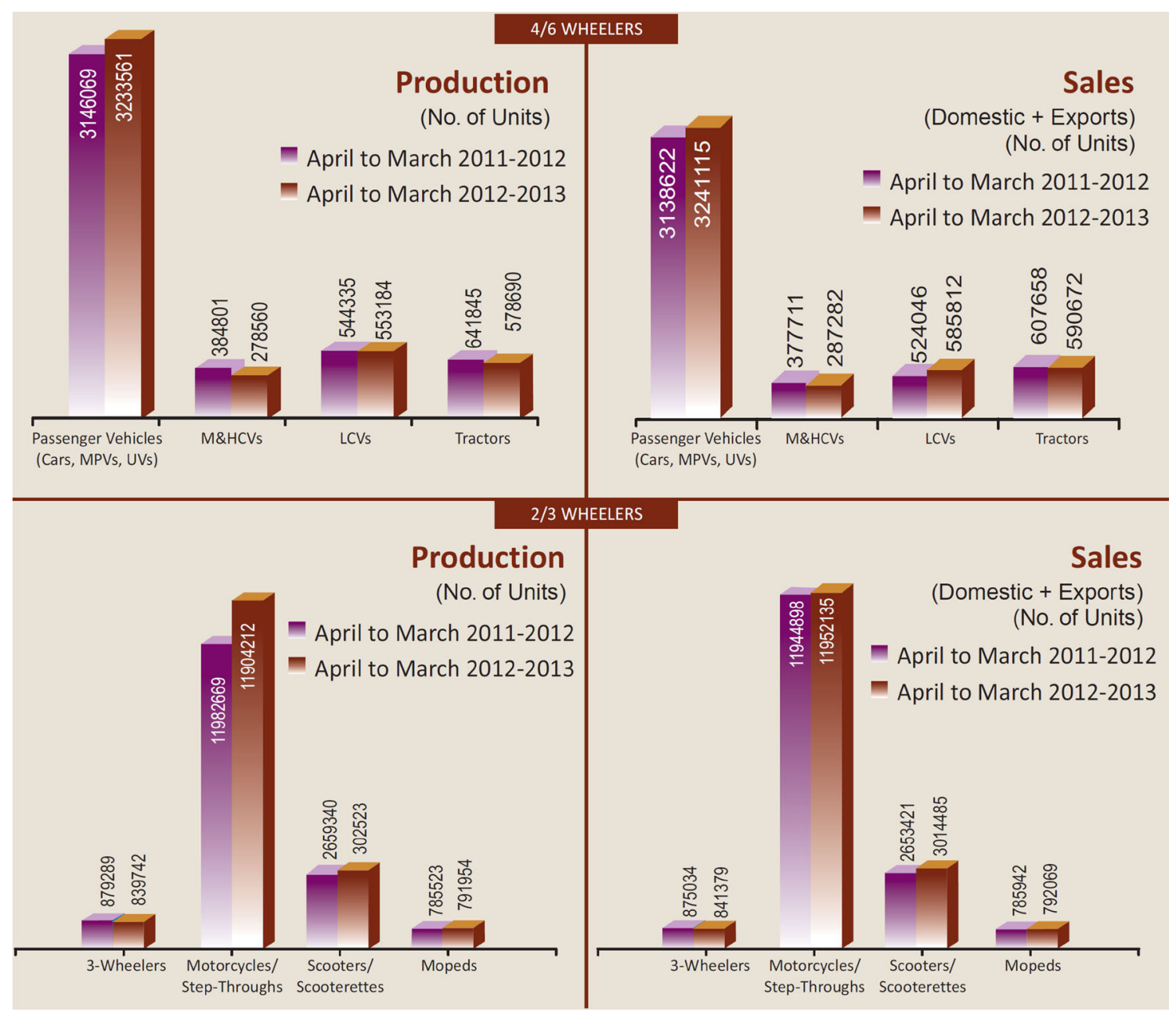

Fig. 3 Automobile industry update (sources: SIAM; ACMA and The Industry 2012-2013)

Aurangabad districts). New hub is being developed at Sanand, Gujarat. South India zone is established in Tamil Nadu (Chennai, Kanchipuram, Krishnagiri, Coimbatore and Tiruvallur districts). East India Cluster is established in West Bengal (Kolkata and Jamshedpur).

The auto and auto components manufacturers (Auto Components, September Auto components 2009) located in various cluster zones are mentioned below.

Major cluster:

1. North/Central zone: Some of the companies established in this zone are Hero Honda, Honda SIEL, Honda Motorcycle \& Scooter India, Maruti Suzuki, Tata Motors, Delphi Auto, JBM, Sona Koyo, Asahi India, Denso India, Lumax and Johnson Matthey.

2. West zone: Some of the companies established in this zone are Daimler, GM, Skoda, Bajaj Auto, Mahindra \& Mahindra, Tata Motors, Volkswagen, Bharat Forge, DGP Hinoday, Kirloskar Brothers, TACO Group, SKF Bearings, Supreme Industries, Bright Brothers, Bosch Chassis, Tata Johnson and NRB Bearings.

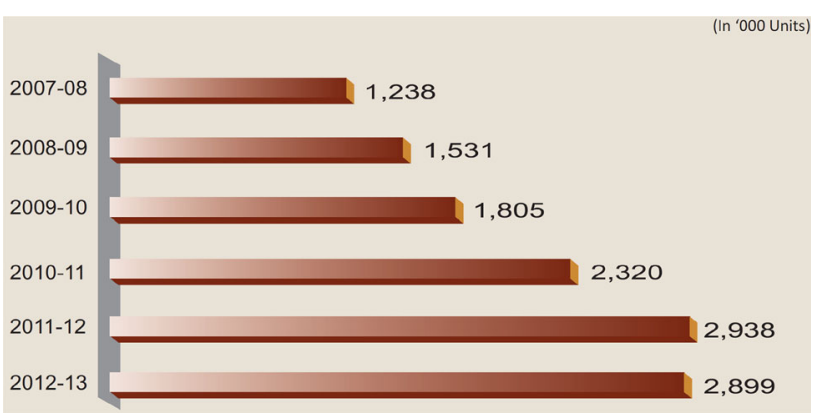

Fig. 4 Indian automobile industry exports (sources: SIAM; ACMA and The Industry 2012-2013)

3. South zone: Some of the companies established in this zone are Ashok Leyland, Ford, TVS Motors, Hyundai, Toyota Kirloskar Motor, Royal Enfield, Volvo, Brake India, Fenner, Rane Group, Visteon, Sundaram Fasteners, Delphi TVS, India Nippon, TI Group, LucasTVS and Ucal Fuel Systems. 
Fig. 5 Automotive clusters in India (source: Auto components, September 2009, www.ibef.org)

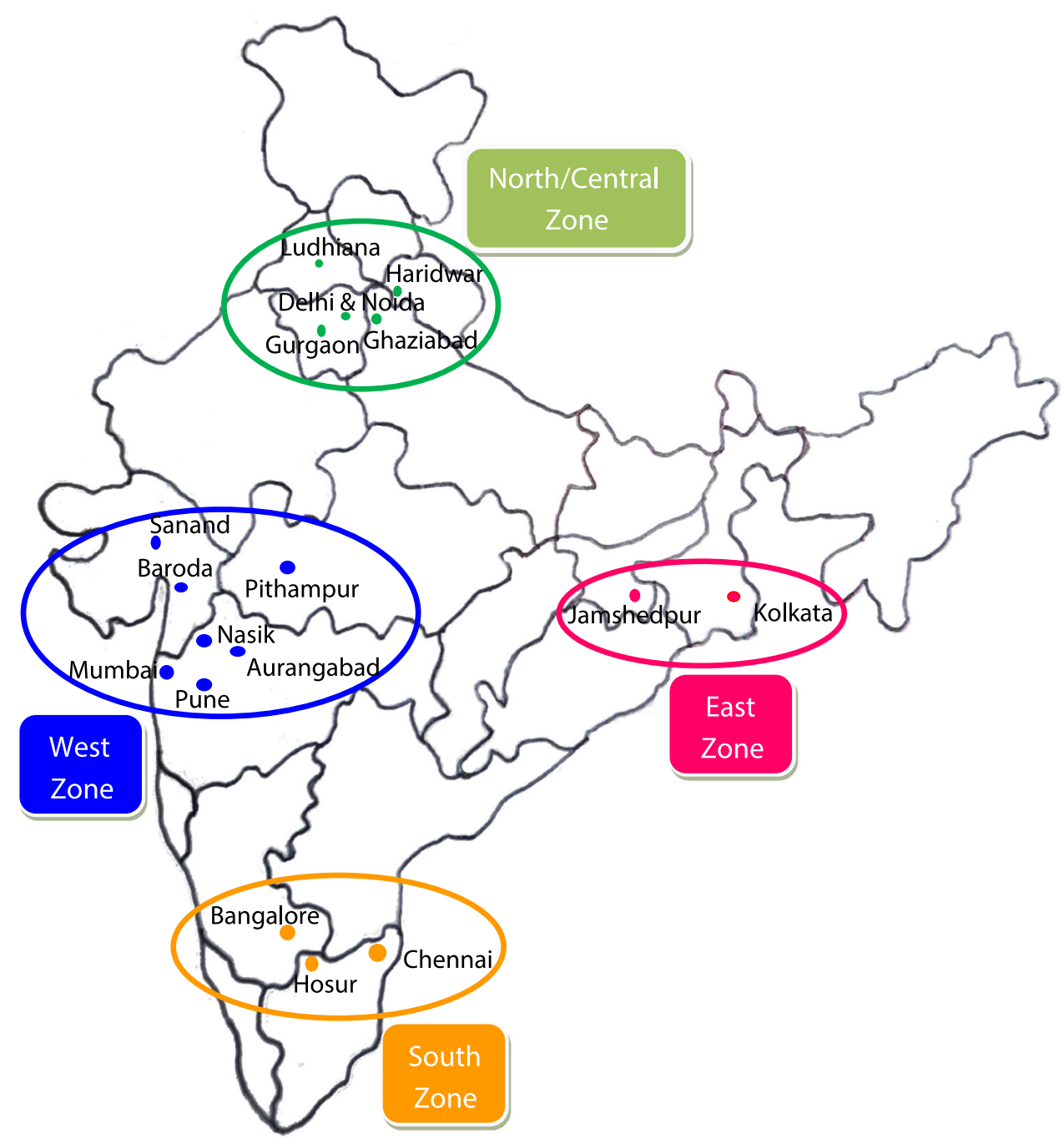

Minor cluster:

1. East zone: Some of the companies established in this zone are Tata Motors, Hindustan Motors, Simpson \& Co, International Auto Forgings, Ramkrishna Forgings, JMT and Exide.

The auto components market is split into six product segments namely engine and engine parts, transmission and steering parts, suspension and braking parts, equipment, electrical parts and others. Figure 6 provides the detail classification of each segment.

Figure 7 depicts auto component industry update. The turnover of Indian auto component industry is almost consistent from 2010-2013. The highest growth in Indian auto component industry was observed in 2010-2011. However, today the auto component industry is experiencing a sharp negative growth.

The auto component industry product range is shown in Fig. 8. Engine parts manufacturing is the largest contributor in component manufacturing. The export destination for 2012 is depicted in Fig. 9. The largest export destination is Europe contributing almost one-third of auto component exports.

\section{United Nations Industrial Development Organization (UNIDO)}

United Nations Industrial Development Organization is the dedicated wing of the United Nations that endorses industrial development for poverty reduction, comprehensive globalization and environmental sustainability. The mandate of the UNIDO is to promote and accelerate sustainable industrial development in developing countries and economies in transition (http://www.unido.org).

Many global automobile OEM companies have set up manufacturing facilities in India. These companies are facing global competition. Localized vendor base capable of supplying quality component is need of these OEM's to alleviate the pressure of global competition. The transformation of existing auto component industry into a tier 


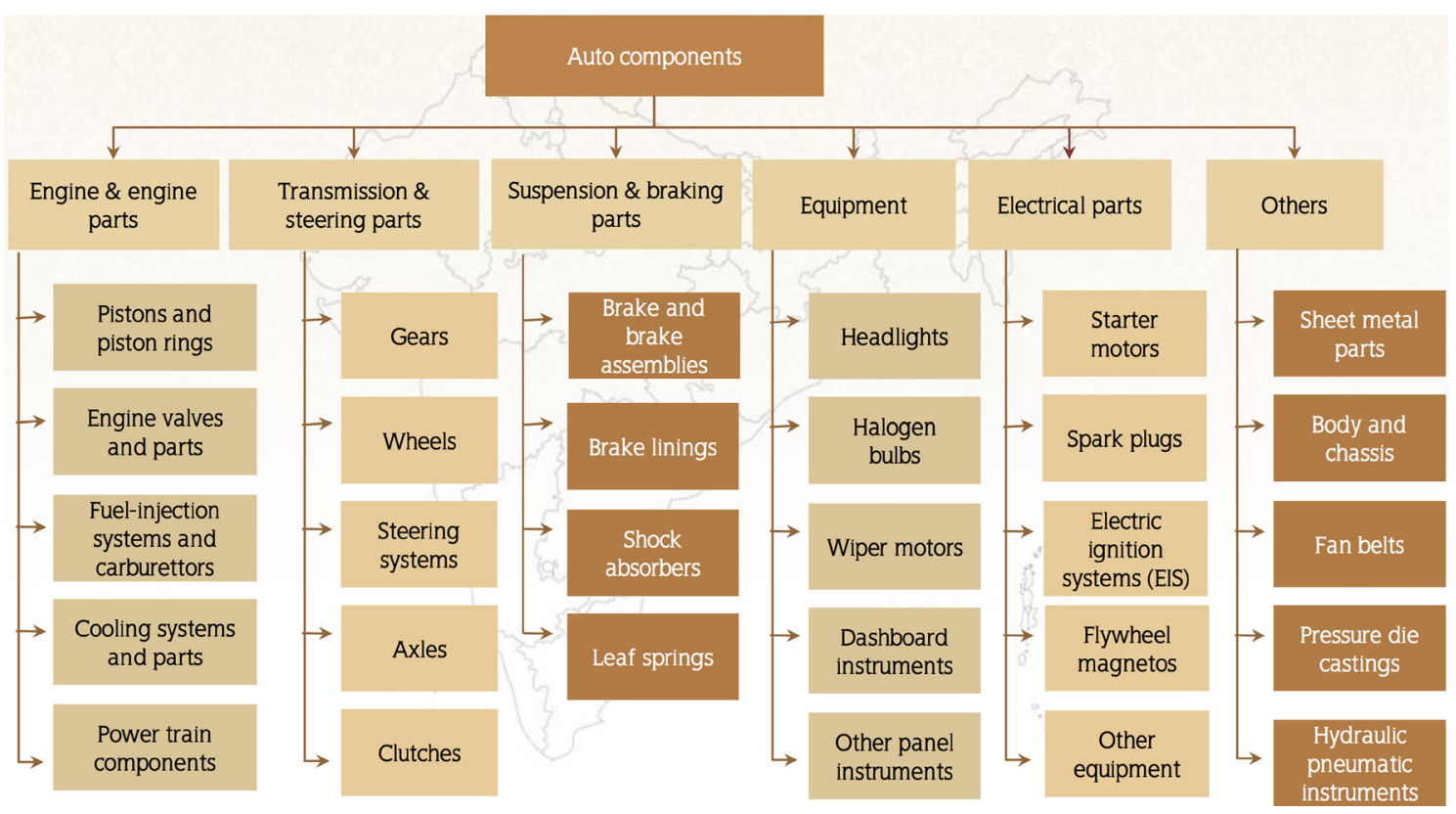

Fig. 6 Product segments of auto components (source: Auto components', November 2011)
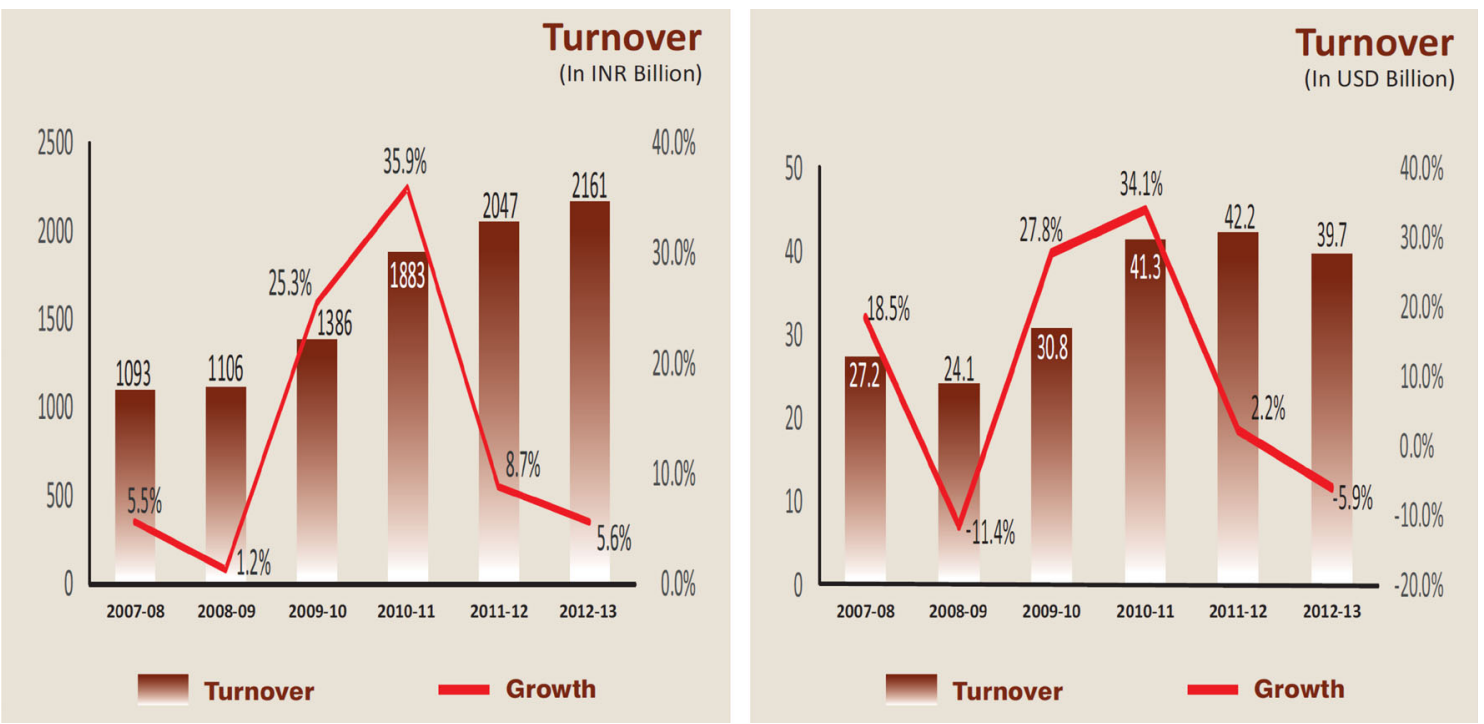

Fig. 7 Auto component industry update (source: ACMA and The Industry 2012-2013)

structure, necessity to acquire world class levels in terms of-quality, productivity and reliability are some of the prerequisites for meeting the requirements of the global automobile OEM's. Moreover, the level of outsourcing for product design, development and manufacturing of various components, sub-assemblies and integrated systems by OEM's has increased many folds. In India, automotive industry is one of the sector in which UNIDO is highly active. UNIDO in collaboration with the Government of India and ACMA launched the UNIDO-ACMA partnership programme for the Indian auto component industry in
November 1998. The purpose is to help Indian auto component manufacturers to alleviate the effects of the abovementioned challenges.

\section{The UNIDO-ACMA Model approach (the partnership roadmap)}

"The UNIDO partnership programme was given its shape through the definition of a 'Road Map'envisaging specific training inputs to firms that, 


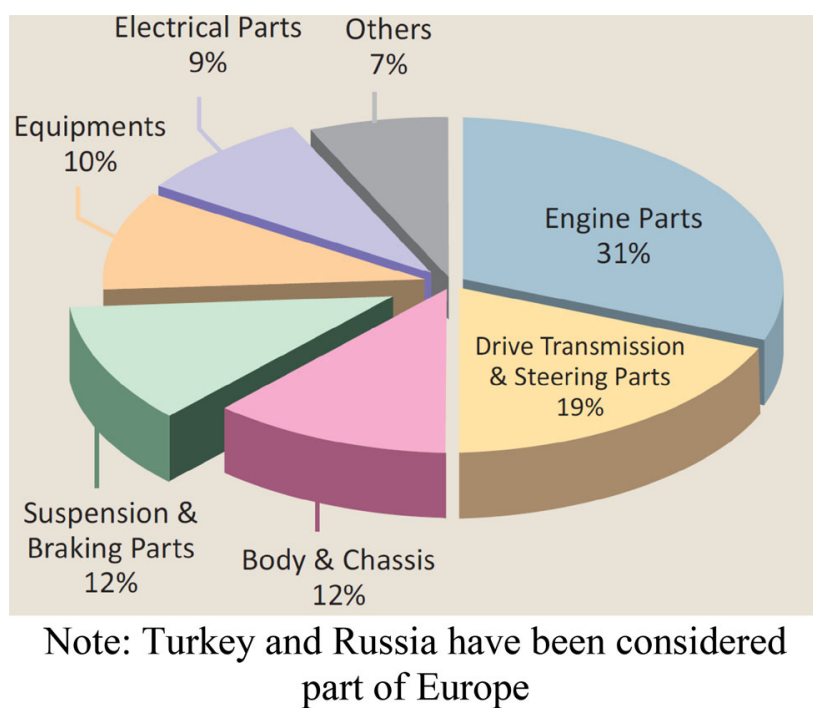

Fig. 8 The auto component industry product range (source: ACMA and The Industry 2012-2013)

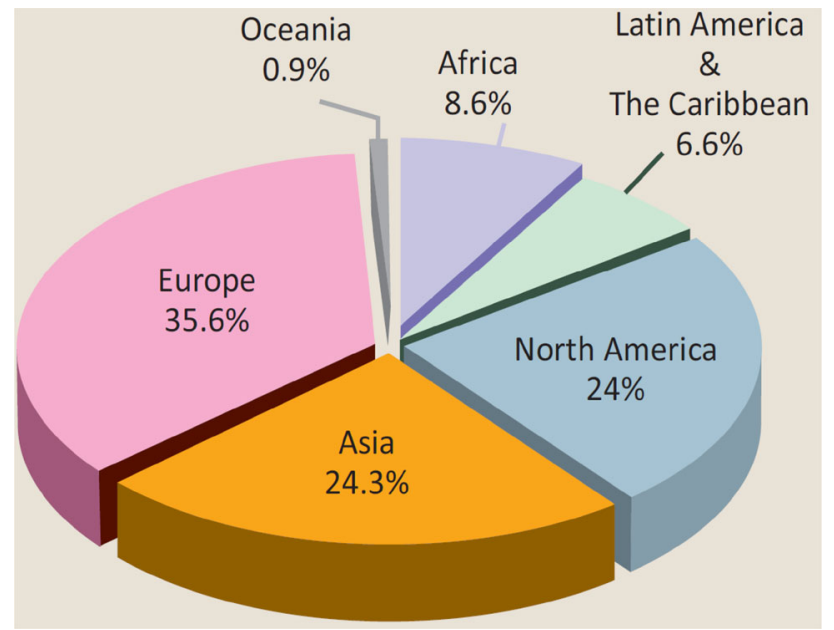

Fig. 9 The export destination for 2012 (source: ACMA and The Industry 2012-2013)

through a process of application at the company level and continuous counseling, would achieve tangible results in terms of improved performance and profits-ultimately leading to a paradigm shift across the automotive component industry to overcome the challenges pointed out above and to take advantage of the manifold business opportunities offered in both the national and global contexts" (UNIDO-ACMA Partnership Programme 2010).

Figure 10 provides the roadmap for the UNIDO-ACMA Model. It describes the model in terms of change process, the input required, the expected results and its impact on business.
The UNIDO-ACMA Model is described in details as follows:

\section{Employee involvement}

Total employee involvement (TEI) is necessary to create Lean organization. To bring about Lean transformation in organization culture, UNIDO-ACMA introduces intensive classroom as well as practical training on Small Group Activity (SCA), Kaizen (Quality Circle), Suggestion Schemes and safety as a first stage of Lean implementation under the guidance of the counselor. Exploring the improvement opportunities, enhancing employee motivation, improving employee involvement, productivity and reducing absenteeism rate are the primary objectives of first stage. The expected results are zero accidents, operator ownership and better involvement of employees in the form of higher number suggestions. These practices lay the foundation for business excellence through improvements in terms of reduced cost, better quality and on-time in-full delivery.

UNIDO-ACMA programme has strong focus on Kaizen on quality improvement, productivity enhancement, cost reductions and safety. Increased employee involvement is essential for improvements on the shop floor and successful implementation of Kaizen. A strong emphasis on the customer and bringing in innovative business ideas based on total employee involvement has rewarded many companies with a steady 'compound annual growth rate' (CAGR).

UNIDO-ACMA Model suggests implementation of safety practices in first stage. Every activity is supposed to evaluate with an emphasis on safety including well-documented safety policy, formation of safety committee, permanent safety measures and safety audits. The combined expert team work approach to identify, define and solve the shop-floor problems helps in rapid development of a "culture of continuous improvement". Development of "continuous improvement culture" is possible with the applications of input techniques like Five S, My machine Campaign (Help in enhancing safety) and waste elimination $(3 \mathrm{M})$ on shop floor and in the organization. The expected outputs are daily management discipline, waste elimination and operator ownership.

\section{S- workplace management}

Workplace organization (5S) and waste elimination (3 M) are combined in second stage of UNIDO-ACMA model. Rigorous and religious 5S implementation naturally laid the foundation for waste elimination. $5 \mathrm{~S}$ is a Japanese concept of workplace organization and improvement. It helps in building a better working environment and a consistently high-quality process. $5 \mathrm{~S}$ is a process for 


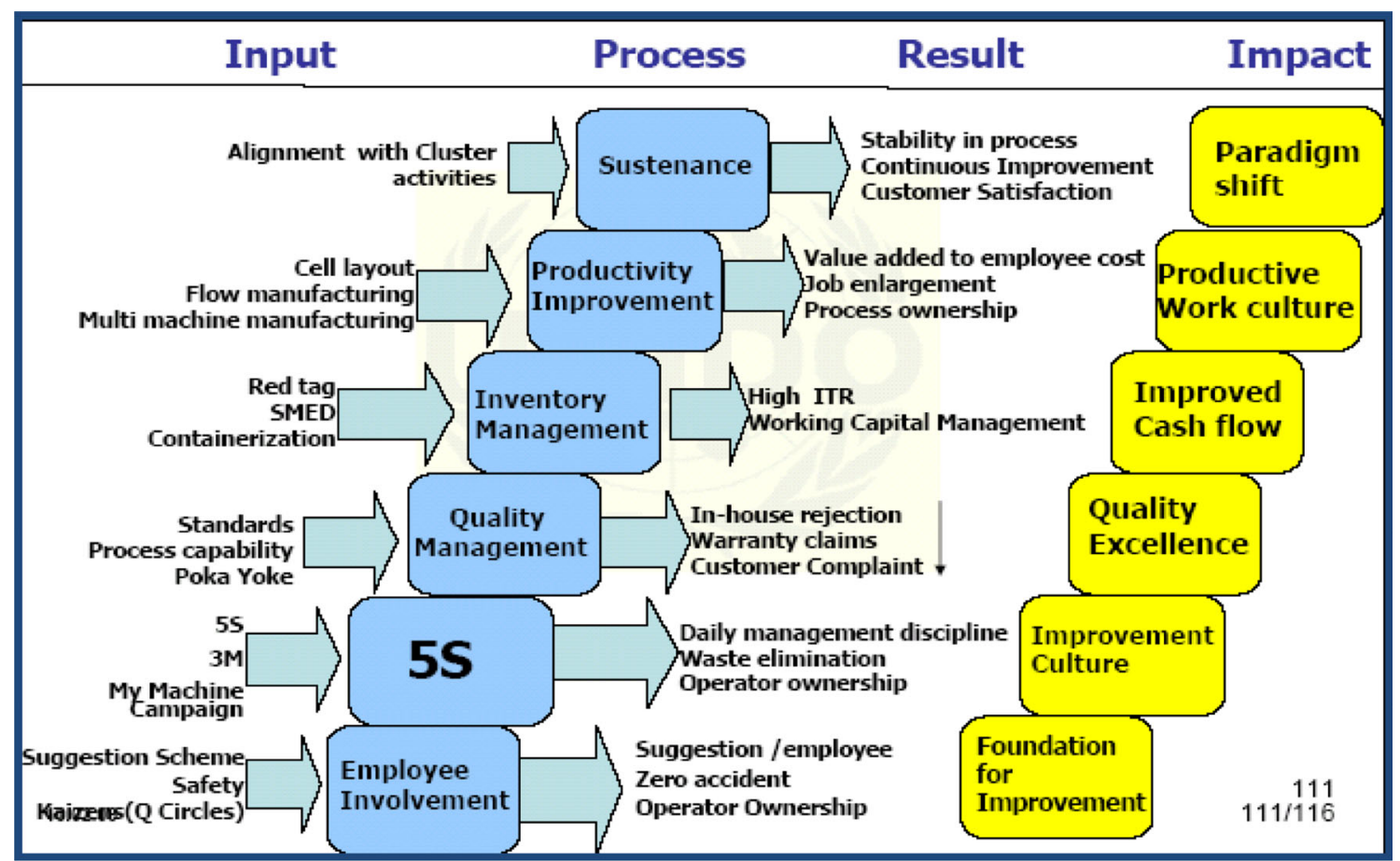

Fig. 10 The UNIDO-ACMA Model approach (UNIDO-ACMA partnership programme 2010)

building and maintaining a workplace which is clean, sanitary, well organized, pleasant, safe and leads to high performance. Effort should be put to avoid all forms of wastages (Muda), reduce or eliminate strains (Muri) and do the things first time right and every time right (Mura or errors).

\section{Quality management}

Achieving excellent quality with minimum utilization of resources and cost is ultimate purpose of quality management. Reducing variation and keeping mean on desired target are very important to maintain and improve the quality. Quality excellence can be achieved through the process of quality management by the application of process capability enhancement, standards and Poka Yoke in third stage of implementation of UNIDO-ACMA Model. The desirable outputs are reduction in in-house rejection, warranty claims and customer claims.

\section{Inventory management}

At fourth stage of UNIDO-ACMA Model, inventory management is very important aspect of any business. High inventory blocks the most important resource, i.e., fund. Minimum inventory or high inventory turn ratio (ITR) is desirable to improved cash flow in the business. Costeffective inventory management is possible through application of use of red tags, quick change over, i.e., single-minute exchange of dies (SMED), small batch size, single-piece flow and containerization. This will help in minimizing the working capital to run the business.

Productivity improvement

Establishment and sustenance of productive work culture are the building block of productivity improvement. This can be achieved through application of Lean techniques such as cell layout, flow manufacturing, multi-machine manufacturing and autonomous maintenance. The expected results are value added to employee cost, job enlargement and process ownership. Final goal of any improvement efforts is the cost reduction. UNIDO-ACMA Model considered inbuilt "Low cost practice".

\section{Sustenance}

Adoption of Lean means embracing change in cultural and attitude. To maintain the momentum of improvement is a challenging task. Many organizations implementing Lean fail to continue the Lean practices by back tracking to the old ways of doing the things.

The ultimate expected impact of Lean implementation is paradigm shift in UNIDO-ACMA Model. This can be achieved through process of sustenance of Lean practices. The desirable results are stability in process, continuous 
improvement and customer satisfaction by aligning with cluster activities.

\section{ISM-based model for Lean practice bundles}

Figure 11 depicts the ISM-based model for Lean practice bundles suggesting the priority order (in phase-wise manner) of Lean practice bundle implementation. The ISMbased model for Lean practice bundles is described in sequence of its implementation in this section

Human resource management practice bundle

According to McNamara (2014), Lean manufacturing has failed to consider human aspects in the past, resulting in undesirable working conditions that can negatively affect commitment, and goes on to identify the role human behaviour plays in the performance of operating systems. Hasle et al. (2012) propose a strong focus on the human side, arguing that Lean must be regarded not only as tools but as an integrated part of a broader sociotechnical system (Oudhuis and Tengblad 2013). HR practices can be conceptualized as the glue that holds the other Lean production practices together (Longoni et al. 2013; de Treville and Antonakis 2006; Cua et al. 2001). The core of Lean adoption is through people, to have workers buy into the ideas and be part of the overall initiative (Tan et al. 2012). Knowledge of individual workers depends on level of team interaction, where the ability to capture and share rapid cycles of learning supports the cornerstone 'expert engineering workforce' (Ringen and Holtskog 2011; Kennedy 2003). Employees must be aware, motivated and trained systematically to make a smooth transition to Lean culture. Lean environment specifically JIT is very dynamic in nature due to pull mechanism. The specific focus must be on HRM practices having impact on cost, quality, delivery and flexibility. The practices in HRM bundle include Quality Circle, communication of goals, effective employee development programs, creating a culture of Lean improvement, rewards and recognition and effective labor management relations.

Creativity and innovation practice bundle

In today's process manufacturing environment, innovation is viewed as critical to sustainable growth and business profitability (Gecevska et al. 2012). According to de Haan et al. (2012), a Lean system continually challenges workers to creatively use their talents, skills, and experience to signal anything that may be identified as waste and to remove impediments to a job well done, thereby improving process control and output quality.
The second phase of ISM Model developed by author advocates use of creativity and innovation practice bundle which consists of Kaizen (continuous improvement) and creative applications of advance technologies. Organizations need to be proactive to delight the customers by satisfying their stated and implied needs. 'Early birds catch more worms' means the manufacture that brings more innovative products early in the market will capture significant market share. This can be achieved by supplying innovative products at affordable price. To tap and convert implicit needs of customer (internal as well as external) into innovative products requires lot of creative thinking. Application of Lean thinking is essential to bring innovative value added products or process early in the market. It was found that the openness, creativeness, and the challenging mentality were found positively influencing the Kaizen transfer (Yokozawa et al. 2010). Innovative applications of advance technologies like enterprise resource planning (ERP) softwares (for examples SAP and Baan), information technology (IT), radio frequency identification (RFID), etc. have brought about tremendous transparency, flexibility, rapid communication, etc. in systems of the organizations.

Health and safety practice bundle

According to Longoni et al. (2013), when Lean is done right it need not be mean, rather Lean should continue to be considered a best practice, not just for its potential to improve operational outcomes but also because of its potential to improve the health and safety of the workers who run the system. Organizations must promote a healthy working environment that is reformed to suit employee's different physical and psychological requirements and capacity. A working environment without risks for health and safety should be a given at every workplace (Johansson and Abrahamsson 2007). Appropriate working environment has to be created keeping health and safety of employees in mind to enhance the productivity. The practices in Health and Safety bundle consist of Five S, Six S, Poka Yoke (mistake proofing) for safety, visual management, standardized work, ergonomic workstation or cell design and total productive maintenance (TPM).

Waste elimination practice bundle

Lean operations are characterized by the elimination of wastes occurring in the manufacturing process, thereby facilitating cost reduction (Vinodh and Chintha 2011; Serrano et al. 2008). Lean manufacturing has been mandated by higher level management as a tool to be used in waste reduction (Green et al. 2010). Waste is nothing but the non-value added activity. Wastes are any procedures, 


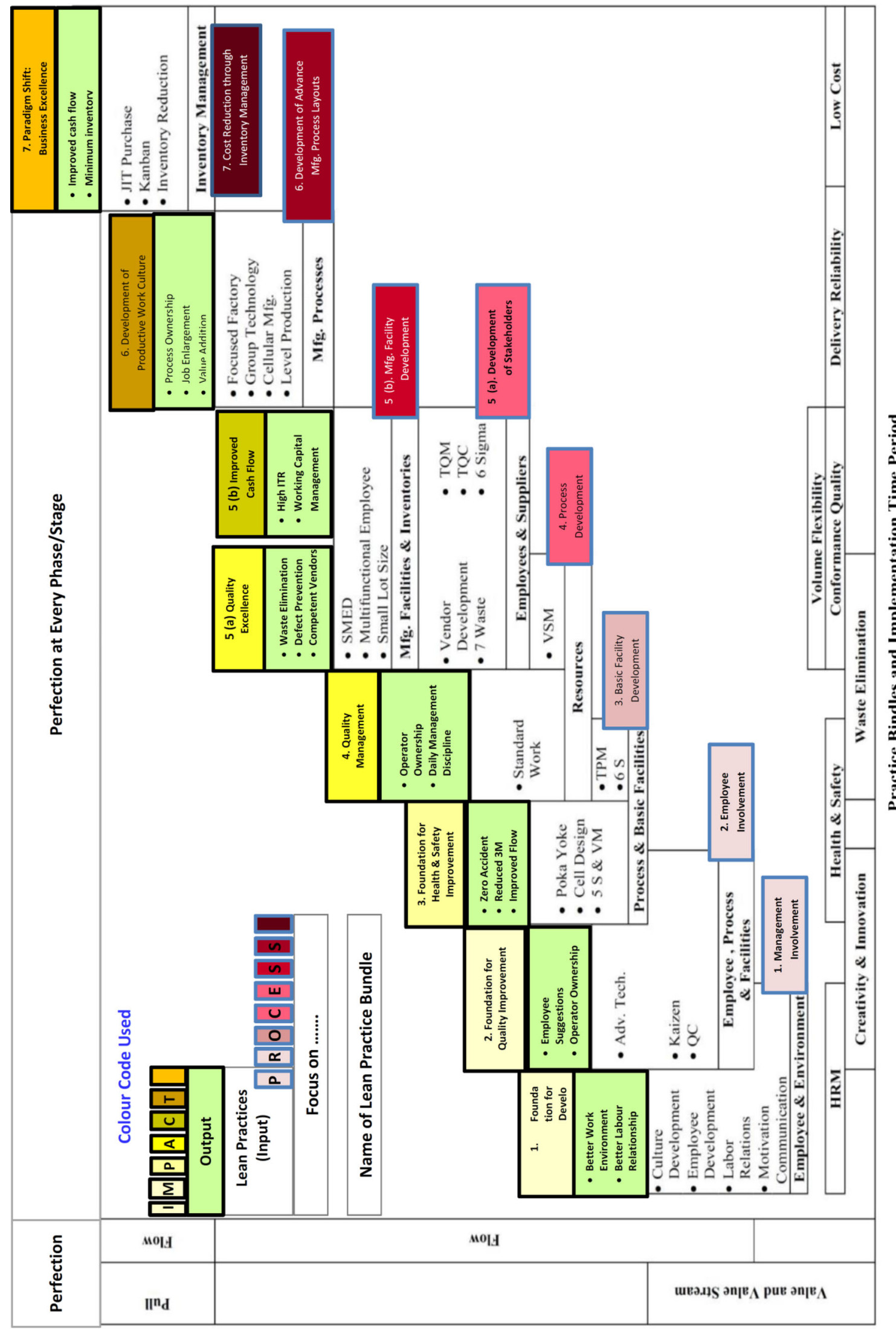

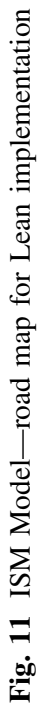


materials, equipment, tools or activities that do not add value and can be eliminated or simplified (Al-Tahat and Eteir 2010). The activity which involves detrimental transformation in shape, size, dimension, taste, color, place or any other desirable characteristic from perception of the customer is called as non-value added activity. Usually wastes are hidden and inflate to the product cost. Understandably, consumers are not willing to pay for waste. So it is very important to detect the sources of waste and eliminate them. Muda, Muri and Mura (3 M) can be eliminated through TPM, standardized work and ergonomic workstation or cell design. Application of these techniques reduces the fatigue and stress on employees thereby improving the health of employees. Obviously, these improvements ultimately lead to enhanced productivity.

\section{Conformance quality practice bundle}

Conformance quality practice bundle is used in fifth phase of ISM Model. It emphasizes on the quality excellence through total quality management (TQM) as well as total quality control (TQC) based on statistical quality control (SQC), statistical process control (SPC) and Six Sigma. Total quality control emphasizes on improving internal quality aspect of business. Naturally, if any organization wishes to improve the quality of product, it can be achieved in isolation without involvement of suppliers. The focal company must develop it limited quality supply base (preferably single source) through supplier management or vendor development programs. Vendor development focuses on enhancing external quality aspect of business. These practices stress on quality improvement in all functions in the organization and in the entire supply chain. Supplier must be treated as seamless extension of the focal company.

\section{Volume flexibility practice bundle}

Application of volume flexibility practice bundle is suggested at fifth level in ISM Model along with conformance quality practice bundle. Flexibility is the ability of a manufacturing system to cope with changes in the nature, mix, volume or timing of its activities (Garg et al. 2001). If the production changes to meet a peak demand, it must use a flexible process that can meet peak demands and still work efficiently during slacker times (Gupta 2011). The production setup must be capable of coping with dynamic demands in short time. Multi-skilled workers and flexible machines capabilities both are equally crucial in Lean manufacturing. The volume flexibility practice bundle consists of setup time reduction, multifunction employees and small lot size/ single-piece flow.
Delivery reliability practice bundle

The customers demand on-time in-full delivery at right place, in exact quantity with specified quality as per the term and conditions of mutual agreement. To fulfill this demand, the manufacturing (supplying) company has to maintain the delivery reliability. Delivery reliability of the organization can be realized with improved flow of material and information throughout the supply chain. The organization's ability to reliably deliver products to the customer may enhance by implementation of focused factory, Group Technology (cellular manufacturing) and uniform workload (production smoothing/Heijunka).

Focused factory attempts to reduce the complexities of the manufacturing process. This may include any or all of the following: simplifying the organizational structure, reducing the numbers of products or processes, and minimizing the complexities of the physical constraints (White et al. 2010). The fundamental idea of Group Technology is to subsume items (e.g., parts, processes, equipment or tools) into families according to their similarity and to take advantage of these groups in order to increase productivity in manufacturing (Bohnen et al. 2011; Shunk 1985). Production smoothing is very critical to make pull production work. More specifically, different variants of a model produced on a shared production line should be distributed over the sequence as evenly as possible (Yavuz 2013). Reduction in batch size and creating the balanced singlepiece flow of the items in entire system are the objectives of production smoothing.

\section{Low-cost practice bundle}

In the face of current economic crunch, companies are looking for the ways to cope with the situation by opting for cost reduction and quality products at the same time (Qureshi et al. 2013). It is well known that profit earned is equal to the difference of market price and cost price of product. Profit can be increased by reducing cost price of product (Singh and Khanduja 2010).

The ISM Model developed by authors considered it as a separate entity at seventh phase/level. It considers the avenues of inventory reduction for radical cost reduction as against incremental cost reduction. JIT implementation demands very high degree of synchronization, communication, commitment, discipline, etc. among supply chain partners. Hence, the focal organization has to attain high level of maturity to implement JIT. The cost reduction is dependent on many successful initiatives of quality improvement programs. That is why it is placed at the final level/phase in ISM Model. The best practices for cost reduction are inventory reduction, Kanban and just-in-time purchasing. 
Sustenance and perfection

"Sustainability is not a method or a tool, it is the state of a company in which the efficiency of resources is maximized, customers are satisfied to a great extent, an improved condition is long-lasting, success is maintained and competitive advantage is sustained" (Hilton 2013; AlSagheer 2011). Sustainability as the embedment of the practice or 'the way we do things round here' (Radnor 2011; Feldman and Pentland 2003).

ISM Model advocates perfection at all phases of Lean implementation. After achieving certain degree of success at each level, it suggests continual improvement at next higher level. Continual improvement acts as a driving force to maintain the zest for improvement through Lean.

\section{Discussion}

The comparison of UNIDO-ACMA Model and ISM Model for Lean implementation is shown in Table 1.

Both, UNIDO-ACMA and ISM approaches are similar in nature. However, ISM approach splits the first-stage interventions (Employee Involvement) of UNIDO-ACMA approach into three phases viz. first phase as human resource management practice bundle, second phase as Kaizen (continuous improvement) as creativity and innovation practice bundle and then partially third health-safety practice bundle. Quality Circle (group-oriented Kaizen) is lower version of intervention as compared to managementoriented Kaizen. Higher version of intervention demands more creative/innovative ideas and systematic thinking to solve the abnormalities or problems. Belongings of process, conducive environment, availability of resources, availability of expert resource persons and systematic problem solving approach are some of the essential prerequisites to implement higher version of interventions.

Numbers of creative ideas are input for an innovative product. New and innovative products/services attract more and more new customers. It also ensures the survival and growth of the organization. High level of creative thinking at enterprise level throughout the supply chain network is necessary to bring more and more innovative business ideas. This can be accomplished through management Kaizen through involvement of intellectual higher cadre employees. High degree of employee involvement is a necessary for shop-floor innovations and successful implementation of management Kaizen. Hence, the authors suggest execution of creativity and innovation practice bundle only after successful installation of first practice bundle, i.e., human resource management which lays the foundation for process and business excellence as well as nurture the organization culture in favor of creative Lean thinking. The top management should devise a system for talent management and knowledge management in the organization.

First two phases of ISM Model works on the development of Lean awareness, Lean culture and continuous improvement. This can be achieved through QC, Kaizen and effective human resources practices. Once the employees are aware and trained in creative thinking, then they can be a great asset in the development of accidentfree and healthy workplace by application techniques like Five S, Six S, TPM, Poka Yoke, visual management, standardized work and ergonomic workstation or cell design, safety Kaizen, etc. Hence, health and safety practice bundle is kept at third phase of Lean implementation.

According to Rose and Deros (2010), the organization no matter the sizes, large or small is crucial to eliminate waste, to increase the profit or return on investment (ROI). Lean relentlessly pursues for eradication of various wastages to make manufacturing system more efficient and effective. Effective waste elimination through high level of interventions like Gemba Walk for identification of Fugai (abnormalities) and value stream mapping is possible. The identification of opportunities for seven types of waste is exposed through value stream mapping, brain storming, Gemba walk for identification of Fugai, etc. Hence, waste elimination practice bundle is placed in phase number four of ISM Model.

Both, quality management of UNIDO-AMA Model and conformance quality practice bundle of ISM Model approaches are similar in nature. With respect to Volume flexibility practice bundle, both approaches are almost identical except development of multifunction employees to enhance volume flexibility. Multi-skilled operators create wide choice for manufacturing different products having different processes. Therefore, the company can satisfy the needs of customers with wide range of products with same human resources and other resources required. Thus, the company can reduce the wastage of skill and talent of its employee.

Delivery reliability practice bundle is useful to ensure the on-time in-full delivery of products. In Group Technology, the components with similar characteristics are grouped together and manufactured in a cell with standard processes. As a result, a small minuscule "focused factories" are being formed as independent manufacturing units within large plants. Cellular manufacturing is based on the principles of Group Technology. The cell layout of machines is usually an U-shaped, to enable smooth onepiece flow production. Cellular manufacturing deploys quick setup, simple machine maintenance by operator himself (autonomous Maintenance), multi-process tools, working on multiple processes and efforts of flexible or multi-functional workforce by means of multi-machine 


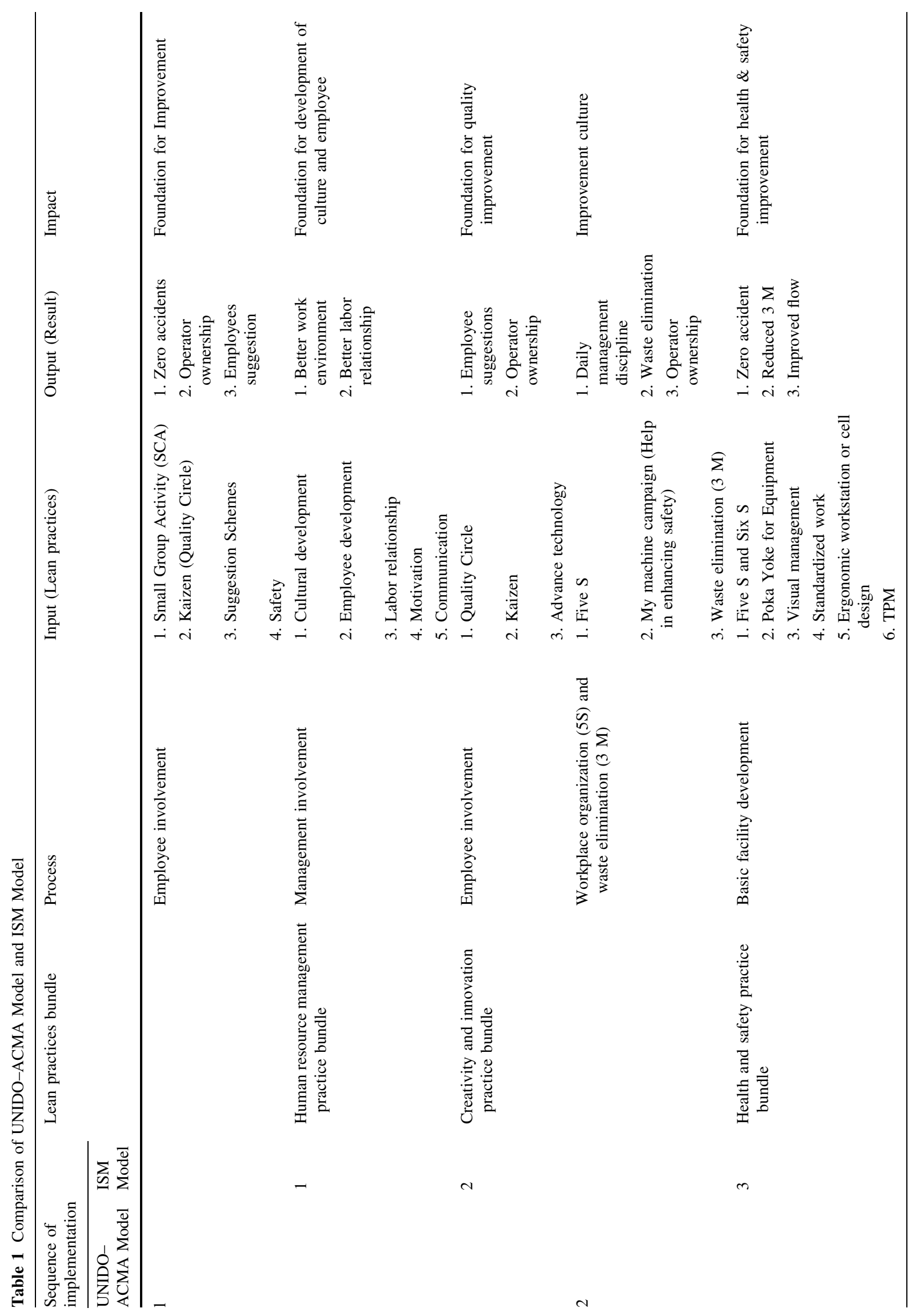




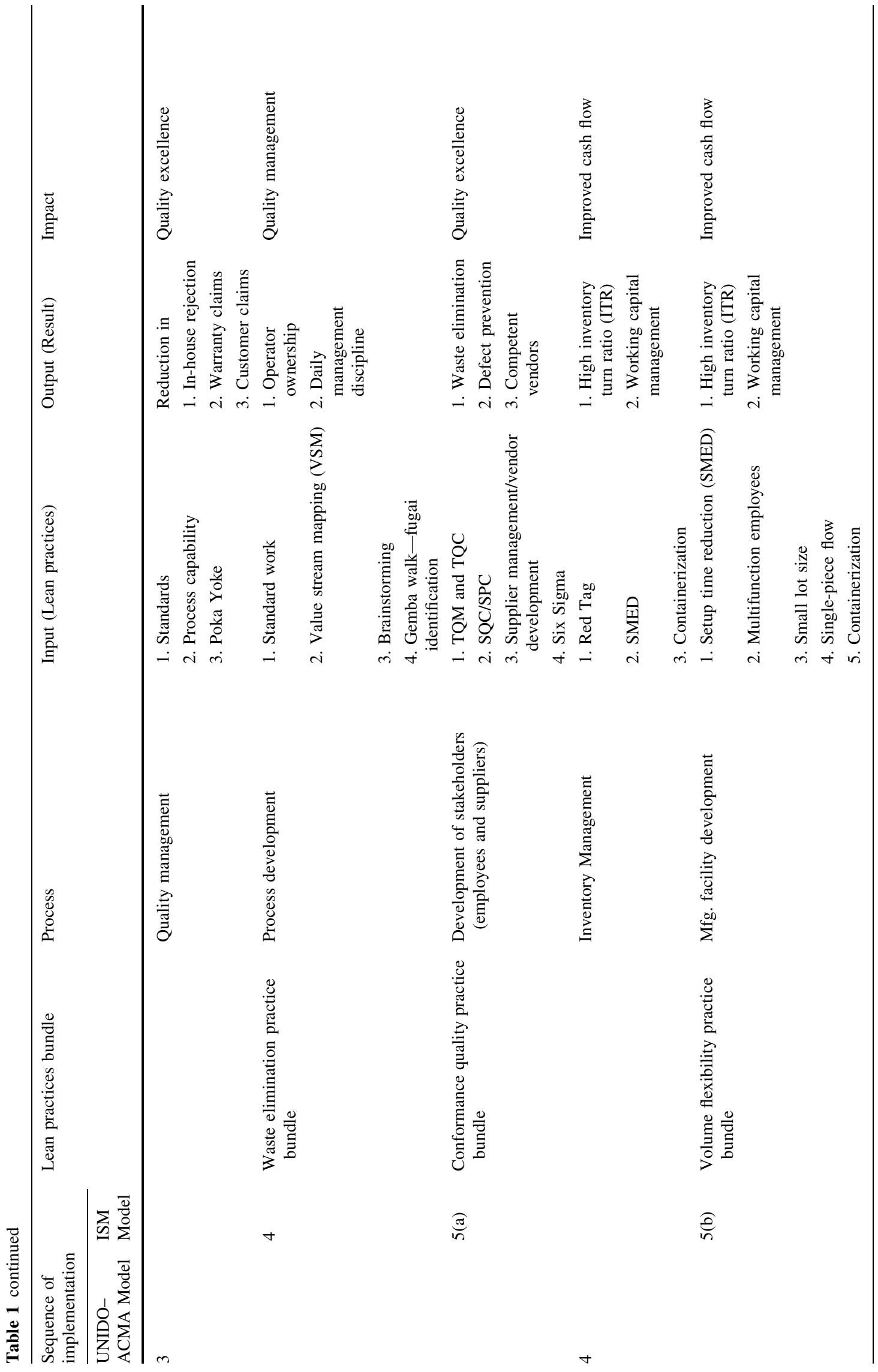




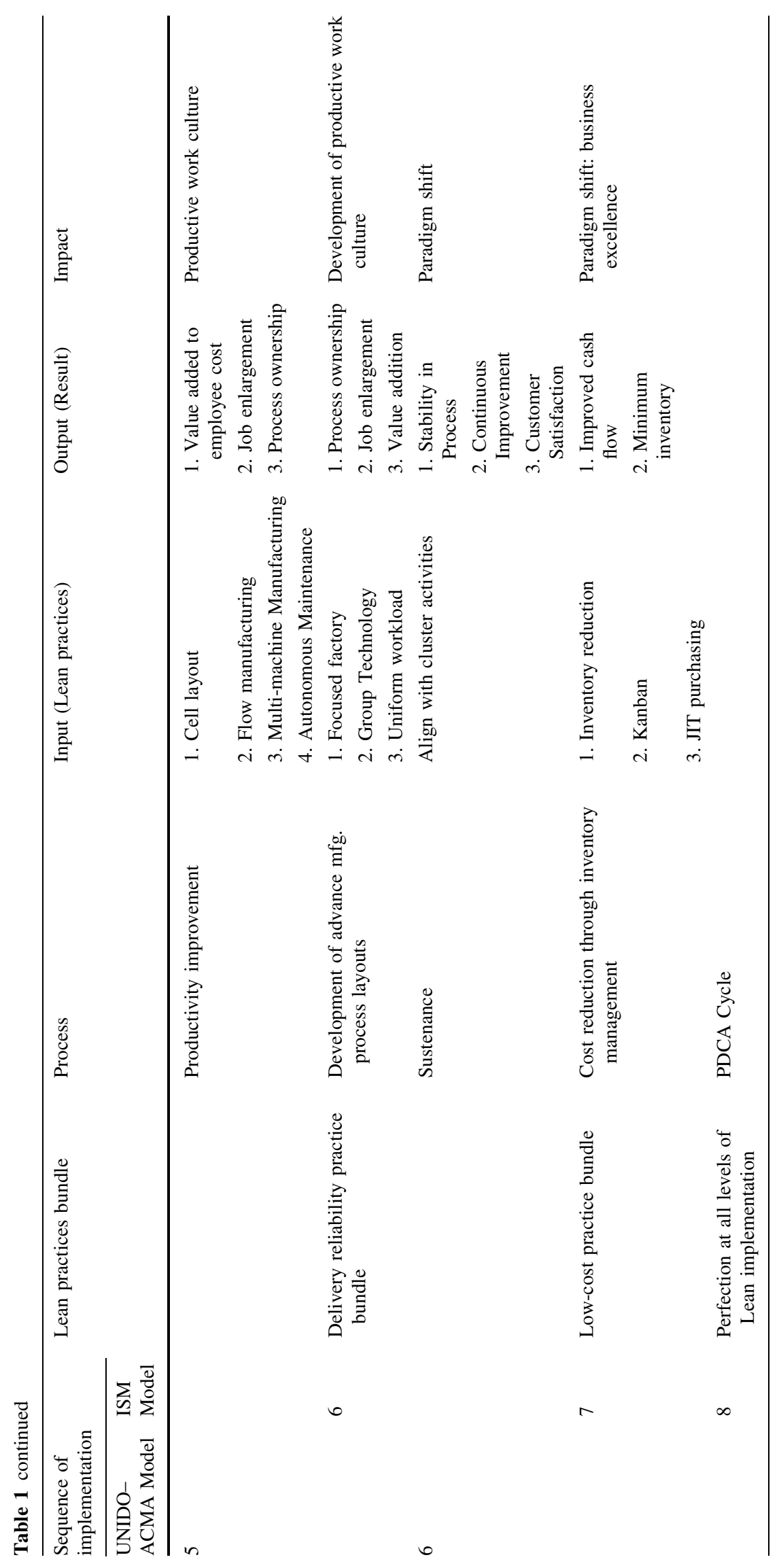


working environment which results in reduction of cumulative lead time. Hence, ISM Model (phase 6) and UNIDO-ACMA Model (stage 5) are similar in nature to improve delivery reliability.

Low-cost practice bundle is vital to keep the cost of products under control. JIT is not only inventory reduction mechanism. The JIT is based on "zero concept", which aims to achieve zero defects, zero queues, zero breakdown, zero inventories and so on. It ensures the supply of right parts in the right quantity in the right place and at the right time. In fact, inventory reduction is perhaps the most visible result that JIT brings about. JIT in reality is a philosophy of supply chain excellence (Roy and Guin 1999). Initially conceptualized as an approach to reduce lead time and decrease inventory within a manufacturing plant (Schonberger 1982), JIT has expanded to include a broader set of production and purchasing practices (Kaynak and Hartley 2006; Fullerton et al. 2003; White et al. 1999; Schonberger and Ansari 1984; Hahn et al. 1983; Schonberger and Gilbert 1983). The deployment and implementation of JIT through Kanban in entire supply network or chain are very essential. Implementation of JIT should not be limited to the focal company but also must be extended to its supplier and distribution network to create true Lean enterprise. Of course, JIT implementation requires lot of investment in various resources to convert existing infrastructure to JIT compactible infrastructure. However, phenomenal benefits will be received through JIT.

Sustenance and perfection are equally important as initiation of improvement. Sustenance and perfection play a vital role in reaping the benefits of improvement in long term. Both models are complementary to each other at this junction. To implement Lean successfully, sustenance of Lean practices and perfection at each phase are absolutely essential. The horizon of UNIDO-ACMA is wider than that of ISM Model. UNIDO-ACMA seeks sustenance of Lean practices throughout the cluster as a single family. Discussions on common platform, benchmarking studies, sharing the lessons learn, etc. are some of the initiatives undertaken by ACMA. ISM Model focuses on successful implementation of Lean in a company.

\section{Conclusions}

Many global automobile OEM and Tier-1 suppliers are setting and expanding the manufacturing facilities in India. The Indian automotive component industry started implementing Lean systems to satisfy the demands of costeffective quality auto components. UNIDO, Automotive Component Manufacturers Association of India (ACMA) and the Government of India launched a joint partnership programme for proliferation of Lean practices in Indian SMEs in various clusters since 1999 under the guidance of trained UNIDO counselors.

The primary objectives of this research are to study and compare the UNIDO-ACMA Model of Lean implementation and corroborate the ISM Model by comparing it with UNIDO-ACMA Model. The secondary objective is to propose an ISM-based framework developed by authors, for successful and sustainable Lean implementation in Indian automotive component industry.

This research is based on compilation of secondary data, which encompass the research articles, web articles, doctoral thesis, survey reports and books on automotive industry in the realm of Lean, JIT and ISM. ISM Model for Lean practice bundles was developed by authors from inputs received from Lean practitioners.

Both, ISM-based Lean Model and UNIDO-ACMA Model were studied and compared to validate ISM-based Lean implementation model in this research. ISM-based Lean Model and UNIDO-ACMA Model approaches are almost similar. The ISM-based Lean implementation model is thus successfully validated through high degree of resemblance with UNIDO-ACMA Model. The significant contribution of this paper is the ISM Model for sustainable Lean implementation. The ISM-based Lean implementation structure offers greater understanding of implementation process at more microlevel as compared to UNIDOACMA Model. ISM Model focuses on successful implementation of Lean in a company where as UNIDO-ACMA seeks sustenance of Lean practices throughout the cluster. To implement Lean successfully, sustenance of Lean practices and perfection at each phase are absolutely essential. ISM-based Lean model advocates implementation of eight Lean practice bundles in sequential order. Application of ISM-based Lean implementation framework offers more clear picture.

\section{Limitations}

This paper primarily focused on Lean implementation in manufacturing segment. The Lean implementation issues in other sectors may slightly differ than manufacturing segment. The issues may vary from country to country, work culture of the organization and geographic location within the country.

\section{Future work}

Lean implementation roadmap based on ISM can be applied in any manufacturing or service industry. The case studies of such efforts can be prepared. 
Acknowledgments The authors wish to thank the anonymous referees for their valuable feedback and constructive comments which helped to improve the structure and quality of this paper.

Open Access This article is distributed under the terms of the Creative Commons Attribution License which permits any use, distribution, and reproduction in any medium, provided the original author(s) and the source are credited.

\section{References}

AlSagheer A (2011) Applying six sigma to achieve enterprise sustainability: preparations and aftermath of six sigma projects. J Bus Econ Res 9(4):51-58. Available at: http://www.cluteinstitute.com/ojs/ index.php/JBER/article/download/4209/4276. Accessed 01 May 2014

ACMA and The Industry (2012-2013). ACMA Annual Report. http:// acma.in/pdf/ACMA_Annual_Report_2012-13.pdf. Accessed 10 Dec 2013

Ahuja V, Yang J, Shankar R (2009) Benefits of collaborative ICT adoption for building project management. Constr Innov 9(3): 323-340

Alawamleh Mohammad, Popplewell Keith (2011) Interpretive structural modelling of risk sources in a virtual organisation. Int $\mathbf{J}$ Prod Res 49(20):6041-6063

Al-Tahat, MD, Eteir, M (2010) Investigation of the potential of implementing Kaizen principles in Jordanian companies. Int $\mathbf{J}$ Prod Dev 10(1/2/3):87-100

Auto components (2009) www.ibef.org. Accessed 15 Dec 2013

Barreto C (2013) Indian auto components industry could outpace China in the coming years. ET Bureau. http://articles.economic times.indiatimes.com/2013-01-10/news/36258336_1_auto-compo nents-industry-indian-auto-capita-income. Accessed 22 Dec 2013

Bohnen F, Maschek T, Deuse J (2011) Leveling of low volume and high mix production based on a group technology approach. CIRP J Manufact Sci Technol 4(3):247-251

CII SR quarterly update (2009) 'CII southern region industry and economic update-auto \& auto components'. http://www.cii.in/ webcms/Upload/Auto\%20and\%20Auto\%20Ancillaries\% 20December20091.pdf. Accessed 6 Dec 2013

Cua KO, McKone KE, Schroeder RG (2001) Relationships between implementation of TQM, JIT, and TPM and manufacturing performance. J Oper Manag 19(6):675-694

de Haan J, Naus F, Overboom M (2012) Creative tension in a Lean work environment: implications for logistics firms and workers. Int J Prod Econ 137(1):157-164

de Treville S, Antonakis J (2006) Could lean production job design be intrinsically motivating? Contextual, configurational, and levelsof-analysis issues. J Oper Manag 24(2):99-123

Diabat A, Govindan K, Panicker V (2012) Supply chain risk management and its mitigation in a food industry. Int J Prod Res 50(11):3039-3050

Faisal MN, Banwet DK, Shankar R (2007) Supply chain agility: analysing the enablers. Int J Agile Syst Manag 2(1):76-91

Farris DR, Sage AP (1975) On the use of interpretive structural modeling for worth assessment. Comput Electr Eng 2(2-3):149-174

Feldman MS, Pentland BT (2003) Reconceptualizing organisational routines as a source of flexibility and change. Adm Sci Q 48:94-118

Fullerton RR, McWatters CS, Fawson C (2003) An examination of the relationships between JIT and financial performance. J Oper Manag 21:383-404

Garg S, Vrat P, Kanda A (2001) Equipment flexibility vs. inventory: a simulation study of manufacturing systems. Int $\mathrm{J}$ Prod Econ 70(2):125-143
Gecevska V, Veza I, Cus F, Anisic Z, Stefanic N (2012) Lean PLMinformation technology strategy for innovative and sustainable business environment. Int J Ind Eng Manag 3(1):15-23

Green JC, Lee J, Kozman TA (2010) Managing lean manufacturing in material handling operations. Int J Prod Res 48(10):2975-2993

Gupta AK (2011) A conceptual JIT model of service quality. Int J Eng Sci Technol 3(3):2214-2227

Hahn CK, Pinto PA, Bragg DJ (1983) Just-in-time production and purchasing. J Purch Mater Manag 19(3):2-10

Hasle P, Bojesen A, Langaa P, Bramming P (2012) Lean and the working environment: a review of the literature. Int J Oper Prod Manag 32(7):829-849

Hilton RJ (2013) Factors critical to a sustainable deployment of lean six sigma in Australian business. Doctoral Thesis in Business Administration, Monash University

India Brand Equity Foundation (IBEF) (2014) Automobile Industry in India. http://www.ibef.org/industry/india-automobiles.aspx. Accessed 14 Jan 2014

Jharkharia S, Shankar R (2005) IT-enablement of supply chains: understanding the barriers. J Enterp Inf Manag 18(1):11-27

Jie, JCR, Kamaruddin, S, Azid, IA (2014) Implementing the Lean six sigma framework in a small medium enterprise (SME) - a case study in a printing company. Proceedings of the 2014 international conference on industrial engineering and operations management Bali, January 7-9. http://iieom.org/ieom2014/ pdfs/86.pdf. Accessed 02 June 2014

Johansson J, Abrahamsson L (2007) The good work-an obsolete vision? 5th International conference on work and learning, Cape Town, South Africa

Kannan G, Pokharel S, Kumar PS (2009) A hybrid approach using ISM and fuzzy TOPSIS for the selection of reverse logistics provider. Res Conserv Recycl 54(1):28-36

Kaynak Hale, Hartley JL (2006) Using replication research for just-intime purchasing construct development. J Oper Manag 24:868-892

Kennedy MN (2003) Product development for the lean enterprise, why Toyota's system is four times more productive and how you can implement it. The Oaklea Press, Richmond

Khurana MK, Mishra PK, Jain R, Singh AR (2010) Modeling of information sharing enablers for building trust in Indian manufacturing industry: an integrated ISM and Fuzzy MICMAC approach. Int J Eng Sci Technol 2(6):1651-1669

Kumar, S., Luthra, S. and Haleem, A. (2013) Customer involvement in greening the supply chain: an interpretive structural modelling methodology. J Ind Eng Int 9(6):1-13. http://www.jiei-tsb.com/ content/pdf/2251-712X-9-6.pdf. Accessed 2 June 2014

Lila B (2012) A survey on implementation of the lean manufacturing in automotive manufacturers in the eastern region of Thailand. 2nd international conference on industrial technology and management (ICITM 2012), IPCSIT vol 49, IACSIT Press. doi:10.7763/IPCSIT.2012.V49.9

Longoni A, Pagell M, Johnston D, Veltri A (2013) When does lean hurt?-an exploration of lean practices and worker health and safety outcomes. Int J Prod Res. doi:10.1080/00207543.2013. 765072

Mandal A, Deshmukh SG (1994) Vendor selection using interpretive structural modeling (ISM)'. Int J Oper Prod Manag 14(6):52-59

McNamara P (2014) Psychological factors affecting the sustainability of 5S lean. Int J Lean Enterp Res 1(1):94-111

Mehta, RK, Mehta, D, Mehta, NK (2012) An exploratory study on implementation of lean manufacturing practices (with special reference to automobile sector industry). Yönetim ve Ekonomi 19(2):289-299. http://www2.bayar.edu.tr/yonetimekonomi/dergi/ pdf/C19S22012/289_299.pdf. Accessed 2 June 2014

Mishra S, Datta S, Mahapatra SS (2012) Interrelationship of drivers for agile manufacturing: an Indian experience. Int J Serv Oper Manag 11(1):35-48 
Mudgal RK, Shankar R, Talib P, Raj T (2010) Modelling the barriers of green supply chain practices: an Indian perspective. Int J Logist Syst Manag 7(1):81-107

Oudhuis Margareta, Tengblad Stefan (2013) Experiences from Implementation of Lean production: standardization versus self-management: a Swedish case study. Nord J Work Life Stud 3(1):31-48

Panizzolo R, Garengo P, Sharma MK, Gore A (2012) Lean manufacturing in developing countries: evidence from Indian SMEs. Prod Plan Control Manag Oper 23(10-11):769-788

Qureshi, MI, Iftikhar, M, Bhatti, MN, Shams, T, Zaman, K (2013) Critical elements in implementations of just-in-time management: empirical study of cement industry in Pakistan. SpringerPlus, 2(645):1-14. http://www.springerplus.com/content/pdf/ 2193-1801-2-645.pdf. Accessed 2 June 2014

Radnor Z (2011) Implementing lean in health care: making the link between the approach, readiness and sustainability. Int J Ind Eng Manag 2(1):1-12. http://www.iim.ftn.uns.ac.rs/casopis/volume2/ ijiem_vol2_no1_1.pdf. Accessed 01 May 2014

Ravi V, Shankar Ravi (2005) Analysis of interactions among the barriers of reverse logistics. Technol Forecast Soc Chang 72(8): 1011-1029

Ringen Geir, Holtskog Halvor (2011) How enablers for lean product development motivate engineers. Int J Comput Integr Manuf. doi:10.1080/0951192X.2011.593046

Rose, AMN, Deros, B, Rahman, MN.Ab (2010) Development of framework for lean manufacturing implementation in SMEs. The 11th Asia pacific industrial engineering and management systems conference. Melaka

Roy RN, Guin KK (1999) A proposed model of JIT purchasing in an integrated steel plant. Int J Prod Econ 59(1-3):179-187

Saboo A, Garza-Reyes JA, Er A, Kumar V (2014) A VSM improvement-based approach for lean operations in an Indian manufacturing SME. Int J Lean Enterp Res 1(1):41-58

Sage AP (1977) Interpretive structural modeling: methodology for large-scale systems. McGraw-Hill, New York, pp 91-164

Sage AP, Smith TJ (1977) On group assessment of utility and worth attributes using interpretive structural modelling. Comput Electr Eng 4(3): 185-198

Satapathy S, Mishra P (2013) A customer oriented systematic framework to extract business strategy in Indian electricity services. J Ind Eng Int, 9(33):1-18. http://www.jiei-tsb.com/ content/pdf/2251-712X-9-33.pdf. Accessed 2 June 2014

Schonberger RJ (1982) The transfer of Japanese manufacturing management approaches to US industry. Acad Manag Rev 7:479-487

Schonberger RJ, Ansari A (1984) Just-in-time purchasing can improve quality. J Purch Mater Manag 20:2-7

Schonberger RJ, Gilbert JP (1983) Just-in-time purchasing: a challenge for US industry. Calif Manag Rev 26:54-68

Serrano I, Ochoa C, De Castro R (2008) Evaluation of value stream mapping in manufacturing system redesign. Int $\mathrm{J}$ Prod Res 46(16):4409-4430

Shunk DL (1985) Group technology provides organized approach to realized benefits of CIMs. Ind Eng 17(April):74-80

Singh BJ, Khanduja D (2010) DMAICT: a road map to quick changeovers. Int J Six Sigma Compet Advant 6(1/2):31-52

Tan KH, Denton P, Rae R, Chung L (2012) Managing lean capabilities through flexible workforce development: a process and framework. Prod Plan Control Manag Oper. doi:10.1080/ 09537287.2011 .646013

Uchikawa S, Roy S (2013) 'The development of auto component industry in India'. http://ihdindia.org/Formal-and-InformalEmployment/Paper-6-The-Development-of-Auto-ComponentIndustry-in-India.pdf. Accessed 6 Dec 2013
UNIDO-ACMA partnership programme (2010) Project phases I-III (1999-2010). Final Report. https://www.unido.org/fileadmin/ user_media/Services/PSD/AUTOMOTIVE/Final\%20Report\%20 India_Layouted.pdf. Accessed 6 Dec 2013

Vinodh S, Chintha SK (2011) Leanness assessment using multigrade fuzzy approach. Int J Prod Res 49(2):431-445

Warfield JW (1974) Developing interconnected matrices in structural modeling. IEEE Trans Syst Men Cybern 4(1):81-87

White RE, Pearson JN, Wilson JR (1999) Just-in-time manufacturing: a survey of implementation in small and large US manufacturers. Manage Sci 45(1):1-15

White RE, Ojha Divesh, Kuo Ching-Chung (2010) A competitive progression perspective of JIT systems: evidence from early US implementations. Int J Prod Res 48(20):6103-6124

Wipro (2013) Step on the gas-steer into the future of the automotive industry in India. Future thought of business, a wipro thought leadership initiative, IND/TMPL/JAN-DEC2013, 5th edn. http:// www.wipro.com/ftob-automotive-isem/downloads/FTOB $\% 20$ Automotive\%20Report\%20WEB.pdf. Accessed 6 Dec 2013

Yavuz Mesut (2013) Iterated beam search for the combined car sequencing and level scheduling problem. Int J Prod Res. doi:10. 1080/00207543.2013.765068

Yokozawa K, Steenhuis, Harm-Jan and de Bruijn, Erik J (2010) The influence of national culture on Kaizen transfer: an exploratory study of Japanese subsidiaries in The Netherlands. Proceedings of The 15th annual Cambridge International Manufacturing Symposium: Innovation in global manufacturing- New models for sustainable value capture, Cambridge, 23-24 September. http://www2.ifm.eng.cam.ac.uk/cim/symposium2010/proceedings/ 24_yokozawa.pdf. Accessed 6 May 2013

J. R. Jadhav obtained his Bachelor of Engineering in Mechanical Engineering from Visvesvaraya Regional College of Engineering, Nagpur (India) in 1995. He completed his Master of Technology in Reliability Engineering from Indian Institute of Technology, Mumbai in 2007. He is a senior faculty in the Mechanical Engineering Department at K. J. Somaiya Polytechnic, Mumbai. He has more than 16 years of experience in Technical Education. He is presently pursuing Ph.D. from Mumbai University, India. His current areas of research include Lean, Six Sigma and innovation. He has specialization in Lean, Six Sigma, TRIZ, ISO, TQM, TPM, SPC, Kaizen and Quality Circles. He is practicing consultant and corporate trainer in quality. As a Six Sigma black belt and Lean practitioner; he has trained over 500 professionals in Lean, Six Sigma, quality and business excellence. He has also executed many quality improvement projects in Indian and multinational industries. More than fifteen of his research papers have been accepted/published in International Journal, International Conferences and National Journals.

S. S. Mantha is the Chairman of All India Council for Technical Education (AICTE). His current areas of research include CAD/ CAM/CAE, Robotics, Automation, Supply Chain Management, etc. $\mathrm{He}$ has more than 30 years of experience in Technical education. He has published number of papers in reputed national and international journals as well as conferences.

S. B. Rane is Associate Professor in Mechanical Engineering Department, Sardar Patel College of Engineering. His current areas of research include Supply Chain Management, Lean, Six Sigma, Industrial Engineering, Manufacturing Management, etc. He has more than 19 years of experience in Technical education. He has published a more than 25 papers in National and International Conferences. He has also published paper in International Journal. 